\title{
CORROSION PERFORMANCE OF SEAWATER CONCRETE WITH FLY ASH UNDER IMPRESSED CURRENT
}

\author{
Cheryl Lyne C. Roxas ${ }^{1}$, Bernardo A. Lejano ${ }^{2}$ and Jason Maximino C. Ongpeng ${ }^{3}$ \\ ${ }^{1} 2401$ Taft Avenue, Manila, cheryl.capiz@ dlsu.edu.ph, De La Salle University - \\ Manila, Philippines \\ ${ }^{2} 2401$ Taft Avenue, Manila, bernardo.lejano@dlsu.edu.ph, De La Salle University - \\ Manila, Philippines \\ ${ }^{3} 2401$ Taft Avenue, Manila, jason.ongpeng@ dlsu.edu.ph, De La Salle University - \\ Manila, Philippines
}

\begin{abstract}
Corrosion of steel is one of the main causes of failure especially in structures located along coastal areas. This process is electrochemical in nature requiring the presence of oxygen and water in order to occur. In this study, fly ash and seawater were incorporated into the concrete mix to address sustainability in construction materials, which encompasses waste and abundant material utilization. Concrete mix proportions with $15 \%$ and $30 \%$ fly ash replacement were designed, with freshwater and seawater as mixing and curing medium. Rectangular column specimens with segmented rebars and stainless steel were cast and subjected to impressed current. Results have shown that specimens with fly ash replacement achieved good corrosion resistance. This may have been attributed to the chlorides in seawater which accelerated the hydration process along with the pozzolonic activity of fly ash, thus improving the microstructure and corrosion resistivity of concrete. Seawater increases early strength when used as mixing water but decreases the strength when used as curing medium. The impressed current technique proved to be effective in accelerating the corrosion rate coupled with the use of seawater.
\end{abstract}

Keywords: seawater concrete, corrosion, impressed current, fly ash

\section{INTRODUCTION}

Along with the potential risk of global warming on the planet, the increase in the demand of resources and cost of construction materials has led to more research on sustainable development. Sustainable development as defined by the World Commission on Environment and Development (WCED, 1987) is the development that meets the needs of the present without compromising the ability of future generations to meet their own needs. It contains within it the concept of needs and the idea of limitations. Recently, the United Nations launched the seventeen (17) sustainable development goals which address global challenges on poverty, inequality, climate, environmental degradation, prosperity, and peace and justice (UNSDG, 2018). This paper aims therefore to contribute in achieving these goals specifically Goal 6: Clean Water and Sanitation, Goal 11: Sustainable Cities and Communities; 
and Goal 12: Responsible Production and Consumption by utilizing alternative materials such as seawater and fly ash in the production of concrete.

The Philippines falls under the little or no water scarcity category but is close to the vulnerability state in terms of freshwater availability (Water, 2012). Thus, strategies need to be developed to avoid reaching the water scarcity and water stress conditions. Being an archipelago, the country comprises more than 7,000 islands. It is also surrounded by vast bodies of water including the Pacific Ocean, West Philippine Sea, Philippine Sea, Sulu Sea and Celebes Sea. Therefore, this abundant resource can be a promising alternative to freshwater especially in construction related processes. However, the use of seawater, particularly in the construction sector, is not practiced because of its evident corrosion effects especially on reinforced concrete structures. The National Structural Code of the Philippines (NSCP) specifies maximum values for water-soluble chloride ion content in reinforced concrete (percent by weight of cement) contributed from ingredients like water, aggregates, cementitious materials and admixtures, i.e., 1.00, 0.30 and 0.15 for dry, moderate and severe exposures, respectively (NSCP, 2013).

Meanwhile, there has been a continuous increase in the production of cement due to its demand in the construction industry. Global cement production will continue to rise until 2030 with 4,830 million metric tons (Statista, 2018). In the Philippines, with the "Build Build Build" infrastructure program of the present administration, there is an expected boom in the cement industry and other construction materials. In 2015, the demand for cement reached a total of 24.4 million tons and this $14 \%$ increase can be attributed to the $20 \%$ public construction growth rate in the same year (CeMAP, 2015). Cement manufacturers in the country have undertaken steps to increase cement production in order to meet the local demand which may continue to increase in the coming years (CeMAP, 2015). Cement production, however, accounts for around 5\% global man-made carbon dioxide emission (CSI, 2015). Fifty (50\%) of emissions come from clinker production, $40 \%$ from burning fuel and 10\% from electricity use and transportation. Therefore, alternatives or substitutes to cement are encouraged to reduce the demand for cement, hence reducing harmful emissions to the atmosphere.

Possible substitutes to cement are fly ash, slag and silica fume which were found to have supplementary cementitious properties. In this paper, fly ash was utilized as partial substitute to cement in combination with seawater in the production of concrete. Fly ash is a by-product produced from the combustion of coal and constitute to about $88 \%$ of the total ash production ((Sandelin \& Backman, 2001); (Swaine, 2000). In the Philippines, coal mainly contributed to the power generation mix at $44.5 \%$ in 2015 while the cement industry utilized $15.22 \%$ of the country's coal supply in the same year (DOE, 2018). With the expected increase of $5.7 \%$ electricity consumption on the average between 2015 and 2020, the country is set to open 23 new coal-fired powerplant by 2020 (Williams, 2015). The high demand for electricity increases the demand for power generation and therefore increases the volume of fly ash produced. Disposal of this enormous amount of ash becomes a problem to most companies in charge of the operations, coupled with the threat of leaching heavy metals and other 
toxic chemicals. Therefore, the use of fly ash as partial replacement to cement can help address the management and disposal of accumulated fly ash. Several studies have proven the benefits of using fly ash as partial substitute to cement because of its pozzolanic properties and reduction in chloride ingress due to its very fine structure. Fly ash has little or no cementitious value but with its reaction to cement components during hydration produces calcium silicate hydrates $(\mathrm{CSH})$, a component with cementitious properties.

In this paper, the effects of utilizing seawater as substitute to freshwater and fly ash as partial substitute to cement were investigated in the context of compressive strength and corrosion resistance. The two materials were hypothesized to complement each other. The corrosive effect of the sodium chloride contained in seawater is balanced by the pore refinement and decrease in porosity from the pozzolanic reaction of fly ash.

\section{MATERIALS AND METHOLOGY}

\section{Material Preparation}

Cylindrical and rectangular prism concrete specimens were cast to determine the compressive strength of concrete and monitor the corrosion behavior of steel reinforcement, respectively. Ordinary Portland cement (OPC) Type 1 served as the main binding material and was partially replaced by weight with fly ash at $0 \%, 15 \%$ and $30 \%$. The chemical compositions of OPC and fly ash are shown in Table 1.

Table 1. Chemical compositions of OPC and fly ash

\begin{tabular}{|c|c|c|c|c|c|c|}
\hline Material & $\mathrm{SiO}_{2}(\%)$ & $\mathrm{Al}_{2} \mathrm{O}_{3}(\%)$ & $\mathrm{Fe}_{2} \mathrm{O}_{3}(\%)$ & $\mathrm{CaO}(\%)$ & $\mathrm{MgO}(\%)$ & $\mathrm{SO}_{3}(\%)$ \\
\hline OPC & 20.10 & 5.40 & 2.78 & 62.30 & 1.60 & 3.21 \\
\hline Fly ash & 54.00 & 29.60 & 5.78 & 4.80 & 1.40 & 0.52 \\
\hline
\end{tabular}

$\mathrm{SiO}_{2}$-Silicon dioxide; $\mathrm{Al}_{2} \mathrm{O}_{3}$-Aluminum trioxide; $\mathrm{Fe}_{2} \mathrm{O}_{3}$-Ferric oxide; $\mathrm{CaO}$-Calcium oxide; $\mathrm{MgO}$-Magnesium oxide; $\mathrm{SO}_{3}$-Sulfur trioxide

Crushed gravel was used as coarse aggregates with a maximum size of $19 \mathrm{~mm}$, while black or river sand was used as fine aggregates. Both were prepared in accordance to the Standard Test Method for Sieve Analysis of Fine and Coarse Aggregates (ASTM C136/C136M-14). Water to cement ratios (\%) were set at 0.40 and 0.60. Freshwater (tapwater) and seawater were used as mixing and curing water. Natural seawater with a salinity of $3.6 \%$ was used to reflect real conditions and application of results. For purposes of mix proportioning of concrete, a slump between $75 \mathrm{~mm}-100 \mathrm{~mm}$ was chosen (beams, RC walls and column application). The mix proportions of concrete as per ACI 211.1 are presented in Table 2. 
Table 2. Mix proportions of concrete

\begin{tabular}{|c|c|c|c|c|c|}
\hline \multirow{2}{*}{ W/C } & \multicolumn{3}{|c|}{$\begin{array}{c}\text { Weight per unit volume } \\
\left(\mathrm{kg} / \mathrm{m}^{3}\right)\end{array}$} & \multirow{2}{*}{ Air (\%) } \\
\cline { 2 - 5 } & $\mathrm{C}$ & FA & CA & W & \\
\hline 0.40 & 460.00 & 732.00 & 820.00 & 184.00 & 3.50 \\
\hline 0.60 & 307.00 & 835.00 & 820.00 & 184.00 & 3.50 \\
\hline
\end{tabular}

W-water; C-cement; FA-fine aggregates; $C A$-course aggregates

\section{Experimental Set-Up}

Concrete mixing was done in accordance to ASTM C192 (Standard Practice for Making and Curing Concrete Test Specimens in the Laboratory). Slump of the concrete was measured in accordance to ASTM C143 (Standard Test Method for Slump of Hydraulic-Cement Concrete). Compressive strength of cylindrical concrete specimens $\left(100 \mathrm{~mm}\right.$ in diameter and $200 \mathrm{~mm}$ in height) was tested at $7^{\text {th }}, 28^{\text {th }}$ and $180^{\text {th }}$ day of curing.

Rectangular prism concrete specimens for structural column simulation were cast. Column size is $100 \mathrm{~mm}$ height by $100 \mathrm{~mm}$ width and $400 \mathrm{~mm}$ length were cast to investigate the corrosion activity of the steel reinforcement. Twelve-millimeter diameter deformed steel bars were used as reinforcement. Segmented steel bars were prepared to facilitate the measurement of macrocell current flowing from one element to adjacent elements. Steel bars were first submerged in $10 \%$ diammonium hydrogen citrate prior to casting to ensure removal of surrounding rust. Figure 1 shows the rectangular prism specimen with the proposed symmetric arrangement of segmented steel bars adopted from (Nanayakkara \& Kato, 2009) with some modifications. Section A and Section B represent the two halves of one specimen. Steel segments measuring $40 \mathrm{~mm}, 60 \mathrm{~mm}$ and $80 \mathrm{~mm}$ were soldered to one another using lead wires and then covered with epoxy to strengthen the bond, making sure that no direct electrical connection exists between the elements except through the wires. Segmented steel bars of but of equal lengths were also used in (Roxas \& Lejano, 2018). A multi-tester was used to ensure proper connection between the wires and steel. The thickness of epoxy layer in between segments was maintained at $3 \mathrm{~mm}$ as much as possible.

Column specimens with and without cold-joints were cast. Cold-joints in the concrete were formed by casting Section A first followed by Section B after 24 hours. After demolding, each surface of the specimen was covered by epoxy except for the surface nearest the concrete cover $25 \mathrm{~mm}$. This is to ensure the diffusion of outside elements through that surface only. All specimens were then cured by total immersion in freshwater and seawater.

The impressed current technique (Maaddawy \& Soudki, 2003) was adopted to induce corrosion in the specimens. A stainless steel bar acted as a cathode while the deformed steel bars served as anodes. A constant voltage from a power source was applied for about four weeks. Table 3 shows the total number of cylindrical and rectangular prism specimens. 


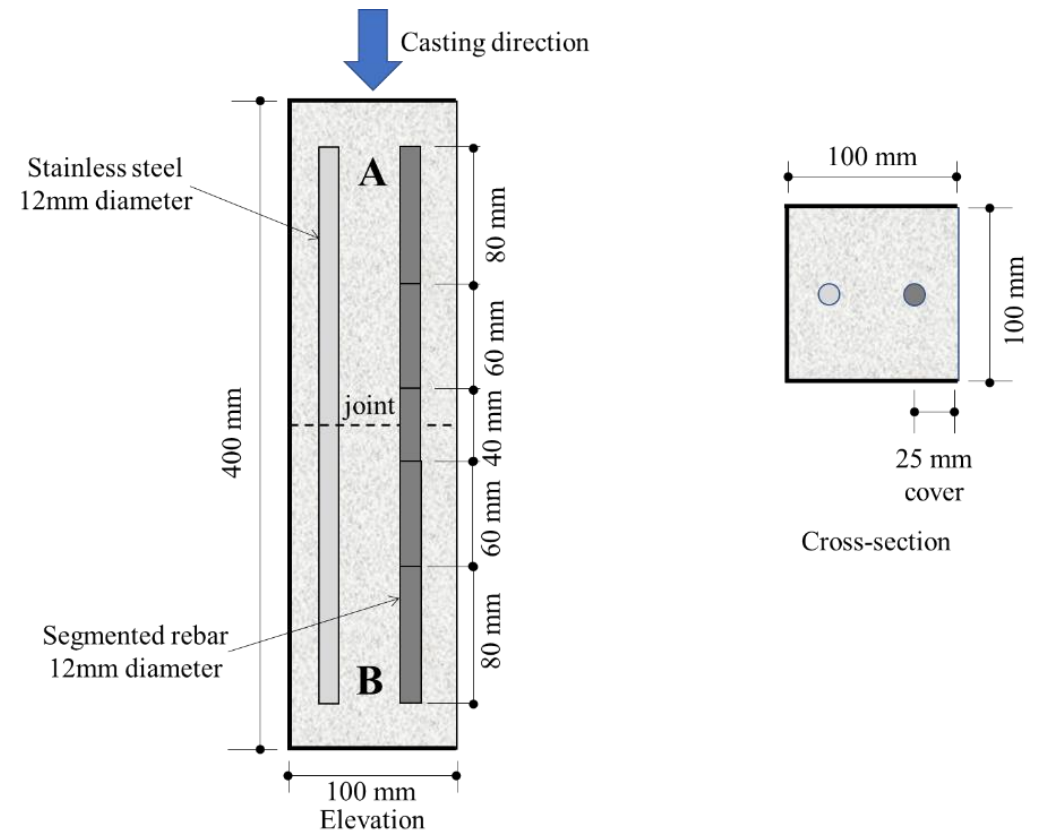

Figure 1. Details for the rectangular prism specimen with segmented steel bars

Table 3. Total number of specimens

\begin{tabular}{|l|l|c|}
\hline \multicolumn{1}{|c|}{ Variables } & \multicolumn{1}{|c|}{ Level } & Total \\
\hline Fly ash replacement & $0 \%, 15 \%, 30 \%$ & 3 \\
\hline Mixing water & Freshwater, seawater & 2 \\
\hline Curing water & Freshwater, seawater & 2 \\
\hline W/C & $0.40,0.60$ & 2 \\
\hline Concrete cover & $25 \mathrm{~mm}$ & 1 \\
\hline Presence of cold-joints & No cold-joint, with cold-joint & 2 \\
\hline Induced corrosion & Non-induced, induced & 2 \\
\hline Compressive strength test days & $7^{\text {th }}, 28^{\text {th }}, 180^{\text {th }}$ & 3 \\
\hline Number of specimens per strength day & & 3 \\
\hline Compressive strength specimens (3 specimens each) & 216 \\
\hline Corrosion specimens (1 specimen each) & 96 \\
\hline
\end{tabular}

\section{Measurement Method and Computations}

The compressive strengths of cylindrical concrete specimens were measured in accordance to ASTM C39 (Standard Test Method for Compressive Strength of Cylindrical Concrete Specimens). On the other hand, the macrocell currents passing through the segmented steel bars were measured weekly using a zero resistance ammeter (ZRA) and a corrosion monitor (CT-7). Macrocell corrosion current is defined as the total electric current flowing through all steel components taken as a unit. Considering Figure 2, this is given by Equation 1 (Miyazato \& Otsuki, 2010). 


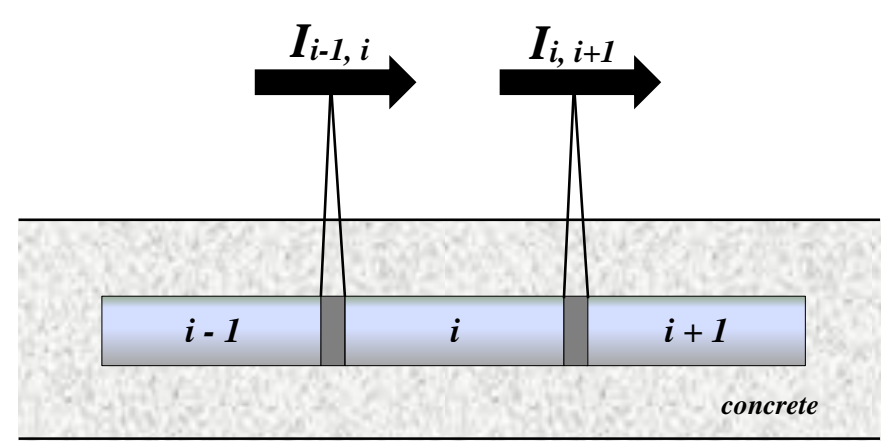

Figure 2. Macrocell corrosion measurement

$$
I_{\text {macro }}=\frac{I_{i-1, i}-I_{i, i+1}}{S_{i}}
$$

Where: $I_{\text {macro }}=$ macrocell current density of steel component I $\left(\mathrm{A} / \mathrm{cm}^{2}\right) ; I_{i-1, i}$ and $I_{i}$, ${ }_{i+1}=$ macrocell corrosion current between steel segments (A); and $S_{i}=$ surface area of steel $i$.

For a corrosion density of $100 \mu \mathrm{A} / \mathrm{cm}^{2}$, the corrosion rate of steel is equal to $1.16 \mathrm{~mm} /$ year (Miyazato \& Otsuki, 2010).

Using the data recorded from the corrosion monitor, the macrocell corrosion can also be calculate using Equation 2 (Baccay, Otsuki, Nishida, Maglangbayan, \& Saito, 2008).

$$
\mathrm{C} 1 \mathrm{~b}=-((\mathrm{E} 1-\mathrm{E} 2) * 1.16 * 1000000) /(\mathrm{Rs} * \pi * \mathrm{~L} * 1.2 * 100) / 1000
$$

Where: $L=$ length of the reinforcing bar segment, $E 1, E 2=$ potential values of opposite sides of segment, $C 1 b=$ macrocell corrosion rate, $R s=$ resistance of reinforcing bar segment.

\section{RESULTS AND DISCUSSION}

The compressive strengths of the specimens under varying w/c ratios, fly ash replacement percentages, mixing water and curing water were tested at $7^{\text {th }}, 28^{\text {th }}$ and $180^{\text {th }}$ day of curing and the results are seen in Figures 3-9. Generally, the strength increased from the $7^{\text {th }}$-day up to the $28^{\text {th }}$ day. However, prolonged curing resulted to a decrease in strength which can possibly be attributed to leaching out of soft hydration products. With respect to w/c, it was confirmed that a lower w/c results to higher compressive strength. In terms of fly ash replacement percentage, the addition of $15 \%$ fly ash led to a minimal increase in strength, while a $30 \%$ replacement resulted to a decrease in values. Seawater used for mixing resulted to a higher early strength while seawater used for curing showed a decrease in strength overall. The highest compressive strengths recorded at the $7^{\text {th }}, 28^{\text {th }}$ and $180^{\text {th }}$ curing were on 0FA-SW-FW0.4 ; OFA-SW-FW-0.4 and OFA-FW-SW-0.6 with values of $55.78 \mathrm{MPa}, 65.94 \mathrm{MPa}$ and $56.85 \mathrm{MPa}$, respectively. On the other hand, the lowest values were seen on specimens 
30FA-FW-SW-0.6, 30FA-FW-SW-0.6 and 0FA-SW-FW-0.6 at 23.69 MPa, 30.79 $\mathrm{MPa}$ and $38.04 \mathrm{MPa}$, respectively. In summary, higher values of compressive strengths were observed at $0.4 \mathrm{w} / \mathrm{c}$ ratio on specimens without fly ash, mixed with seawater and cured in freshwater.

Table 4. Batch description

\begin{tabular}{|c|c|c|c|c|}
\hline Batch No. & $\mathrm{w} / \mathrm{c}$ & FA\% & Mixing Water & Curing Water \\
\hline 1 & 0.4 & 0 & FW & $\mathrm{FW}$ \\
\hline 2 & 0.4 & 15 & FW & FW \\
\hline 3 & 0.6 & 0 & FW & FW \\
\hline 4 & 0.4 & 0 & SW & FW \\
\hline 5 & 0.6 & 0 & SW & FW \\
\hline 6 & 0.4 & 15 & SW & FW \\
\hline 7 & 0.6 & 15 & SW & FW \\
\hline 8 & 0.4 & 30 & SW & FW \\
\hline 9 & 0.6 & 30 & SW & FW \\
\hline 10 & 0.6 & 15 & FW & FW \\
\hline 11 & 0.6 & 30 & FW & FW \\
\hline 12 & 0.4 & 30 & FW & FW \\
\hline 13 & 0.4 & 0 & SW & SW \\
\hline 14 & 0.6 & 0 & SW & SW \\
\hline 15 & 0.4 & 15 & SW & SW \\
\hline 16 & 0.4 & 30 & SW & SW \\
\hline 17 & 0.6 & 0 & FW & SW \\
\hline 18 & 0.4 & 0 & FW & SW \\
\hline 19 & 0.6 & 30 & SW & SW \\
\hline 20 & 0.6 & 15 & SW & SW \\
\hline 21 & 0.4 & 15 & FW & SW \\
\hline 22 & 0.6 & 15 & FW & SW \\
\hline 23 & 0.4 & 30 & FW & SW \\
\hline 24 & 0.6 & 30 & FW & SW \\
\hline
\end{tabular}




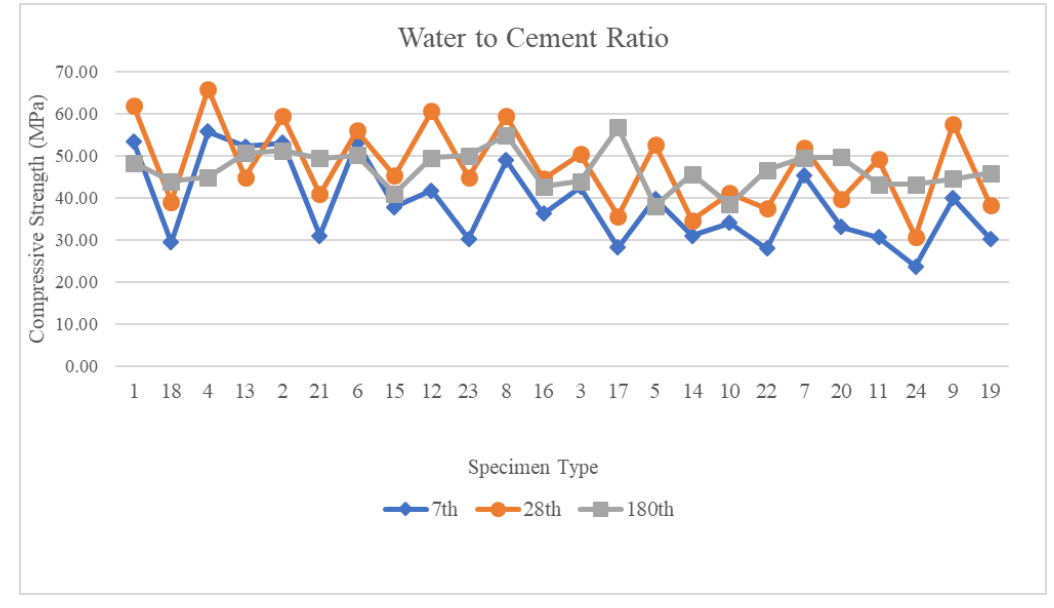

Figure 3. Compressive strength of specimens with respect to water to cement ratio

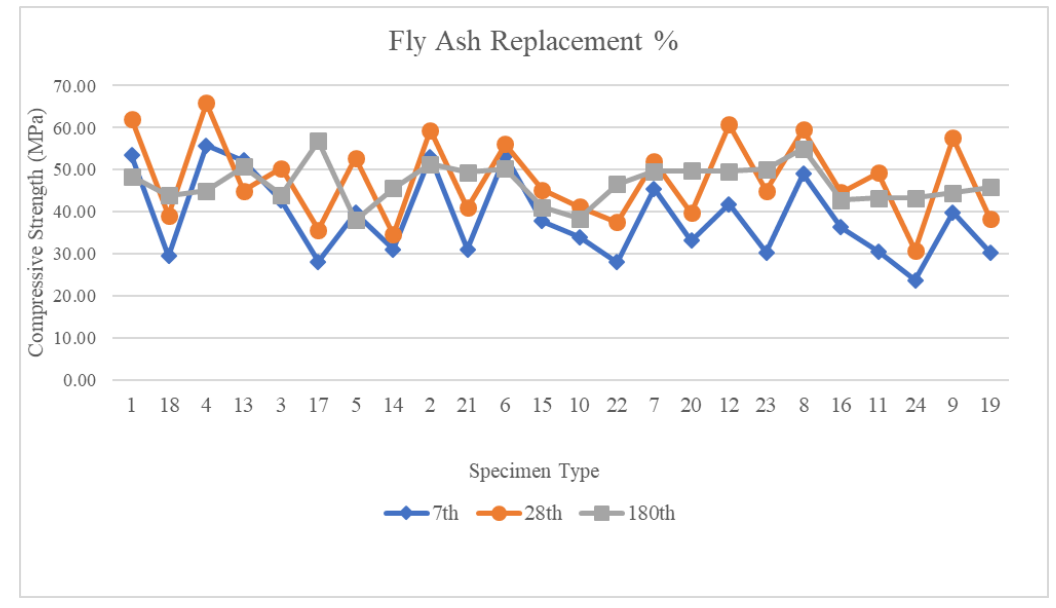

Figure 4. Compressive strength of specimens with respect to fly ash replacement \%

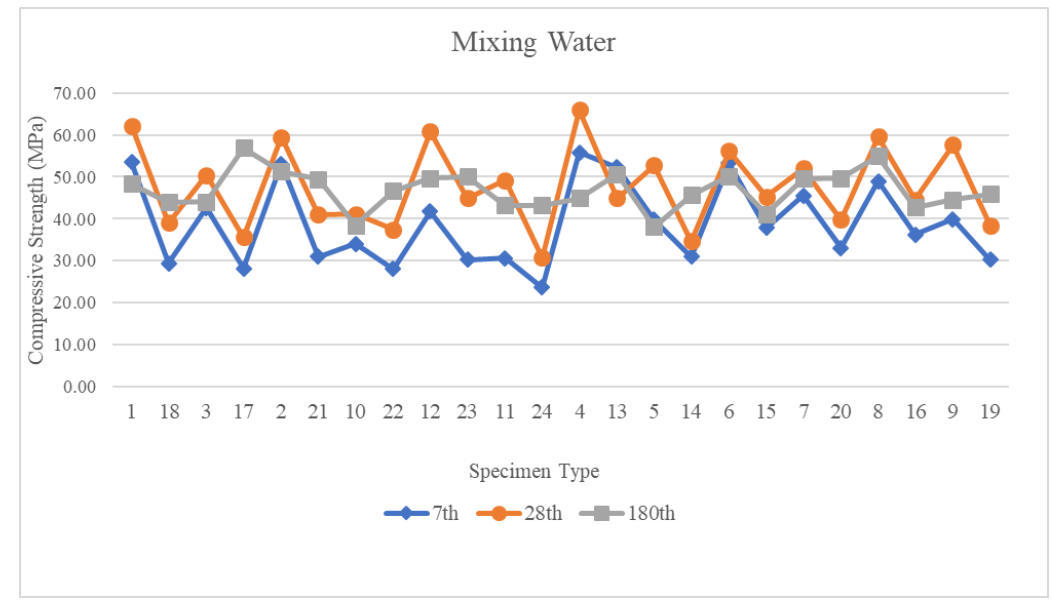

Figure 5. Compressive strength of specimens with respect to mixing water 


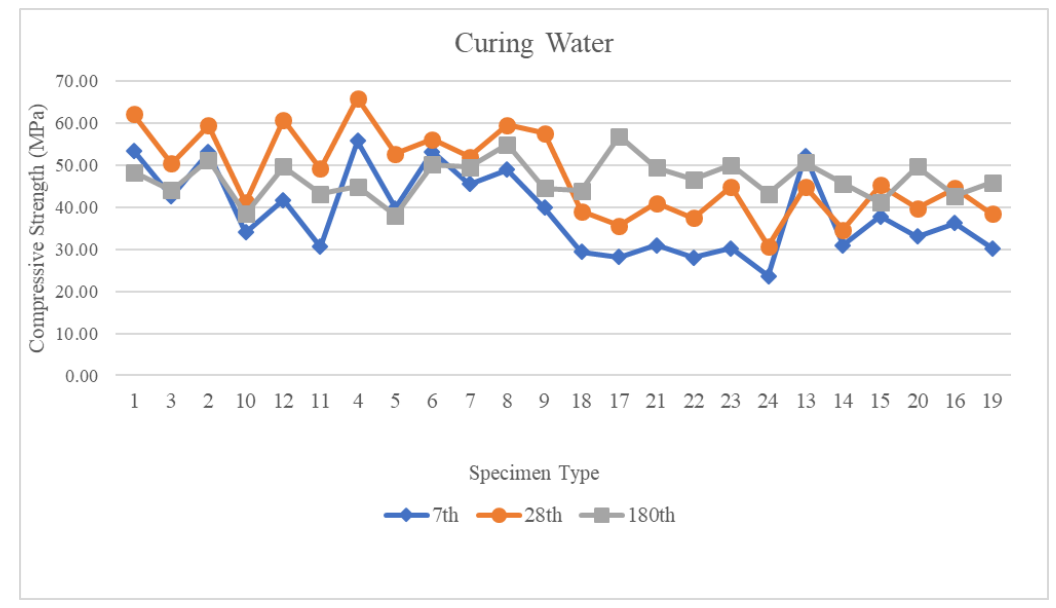

Figure 6. Compressive strength of specimens with respect to curing water

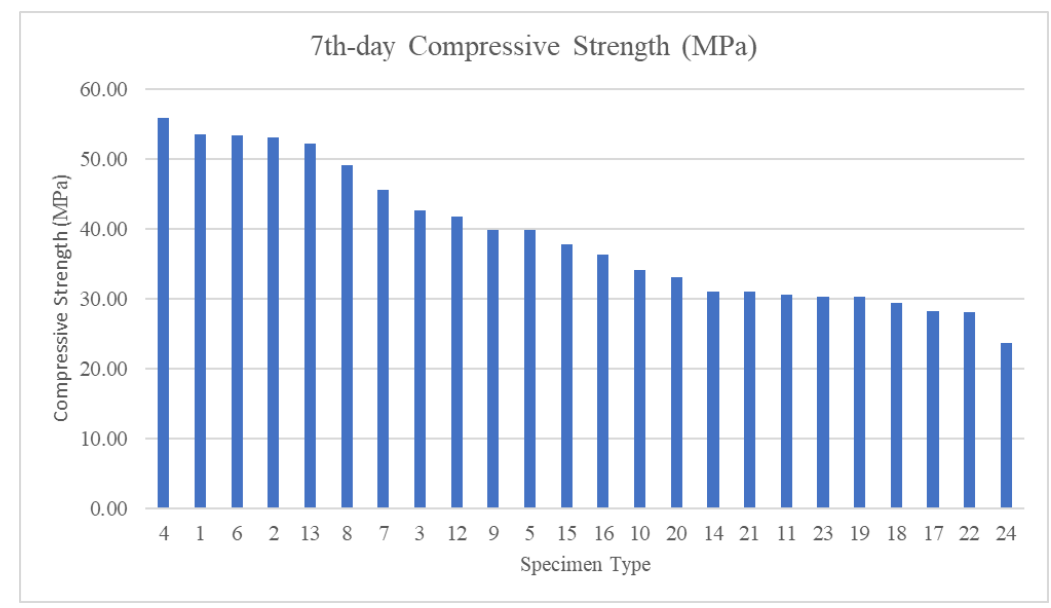

Figure $7.7^{\text {th }}$-day Compressive strength of specimens (MPa)

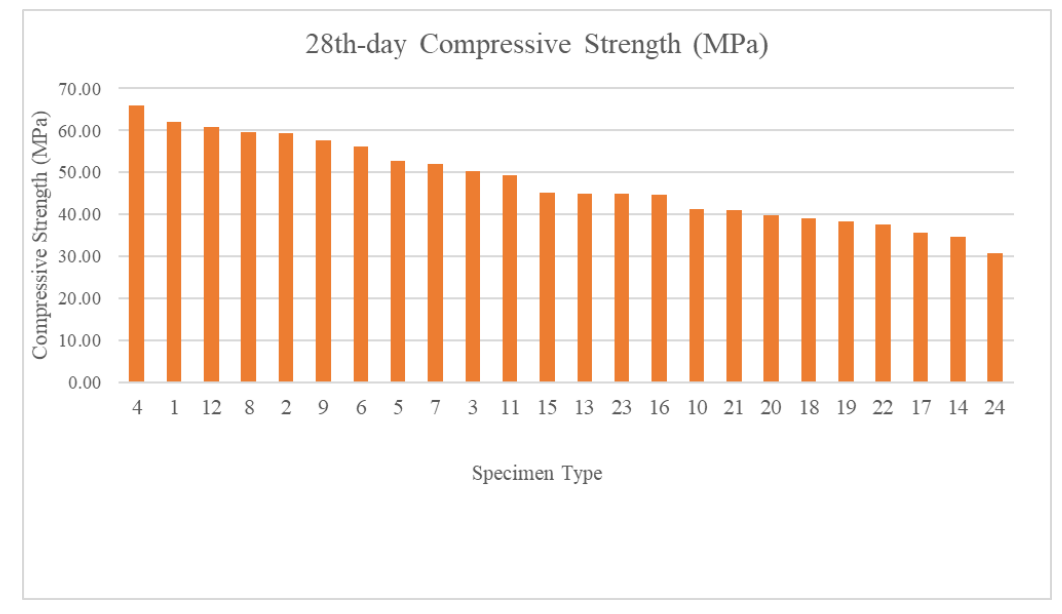

Figure 8. $28^{\text {th }}$-day Compressive strength of specimens (MPa) 


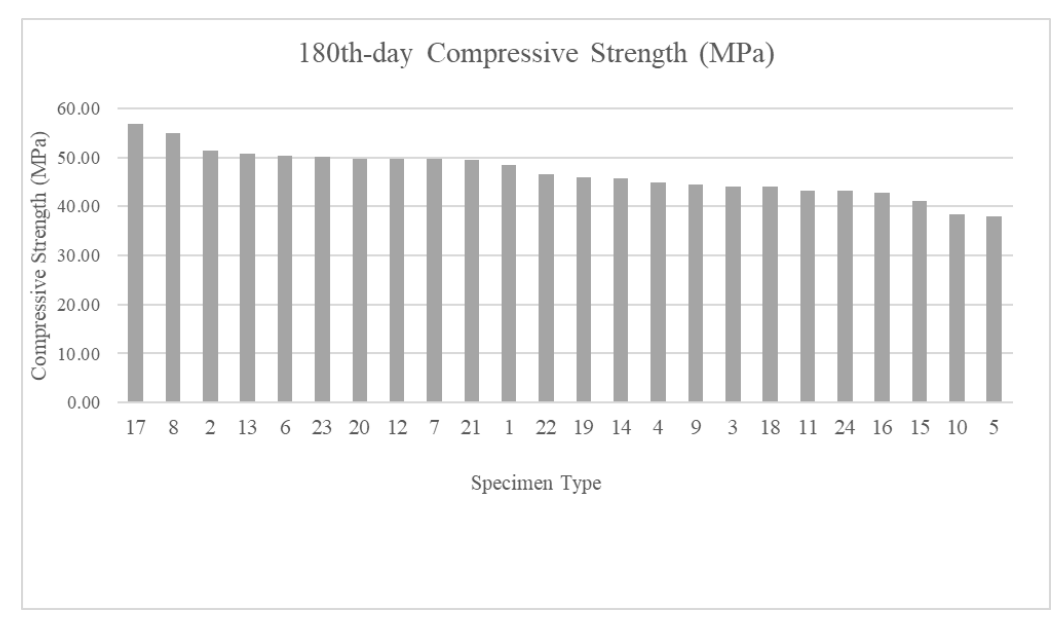

Figure 9. $180^{\text {th }}$-day Compressive strength of specimens (MPa)

In terms of corrosion rate as seen in Figures 10 and 11 (Refer to Table 4 for the batch description), relatively flat graphs can be observed which depict lower values of macrocell corrosion. Previous studies have also shown that macrocell corrosion is lower compared to microcell corrosion. Also, specimens with cold-joints and subjected to ICT obtained higher corrosion rates. However, it can be noted that higher corrosion values are concentrated on the top and bottom segments (segments 1 and 5) rather than the middle segment 3 where the cold-joint is located. The negative values in the corrosion rates only denote the direction of current passing thru the column.

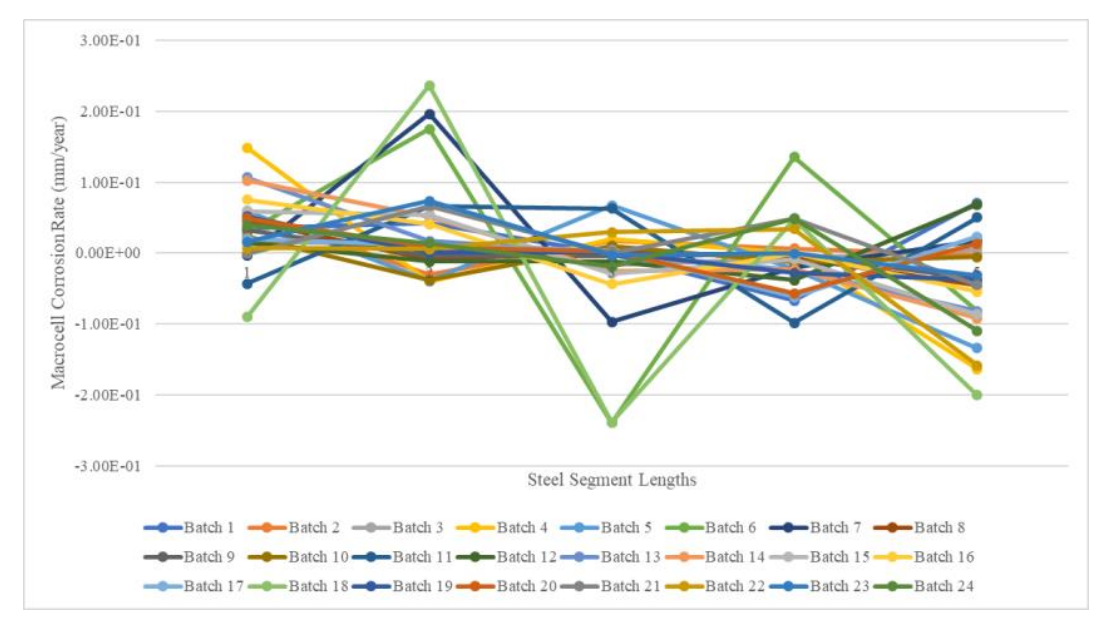

Figure 10. Macrocell corrosion rate for specimens with no cold-joint and no ICT 


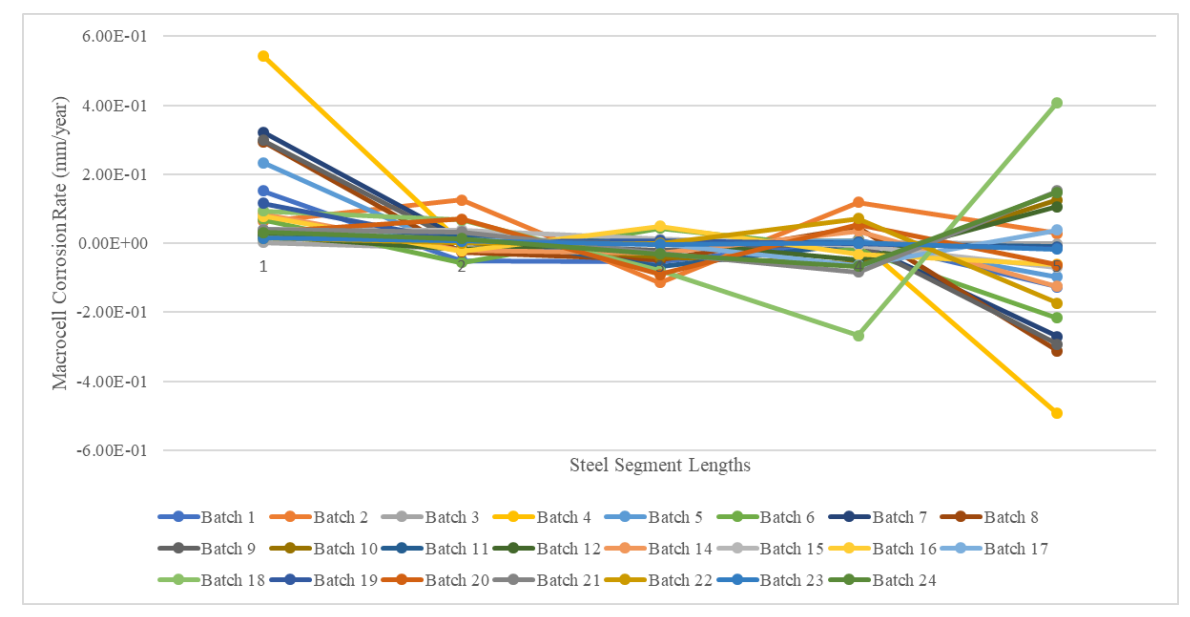

Figure 11. Macrocell corrosion rate for specimens with cold-joint and ICT

\section{CONCLUSION}

This paper aims to determine the effects of utilizing fly ash and seawater as components of concrete in terms of the compressive strength and macrocell corrosion rate. From the results, the following were concluded. First, specimens with $15 \%$ fly ash achieved an increase in compressive strength while a $30 \%$ replacement resulted to a decrease in strength. Specimens with fly ash showed a decrease in corrosion rate. Second, seawater when used as mixing water showed higher early strength but decreased the strength when used as mixing water, specifically for those with $30 \%$ fly ash. This implies that a certain limit to the amount of fly ash used in concrete imposed in order to achieve the best results. It was also evident that seawater increased the corrosion rate of the steel bars in concrete. Third, the impressed current technique proved to be effective in accelerating the corrosion process of steel in concrete, especially when the concrete in mixed with seawater.

The use of seawater in concrete may be a promising solution to the water scarcity facing the world today. However, due to its corrosive components, its application to the construction industry is still pending. But with proper and correct combination with corrosion resisting agents such as fly ash, it may be recommended in the near future, especially for disaster stricken areas where obtaining freshwater is difficult and reconstruction of damaged structures is immediately required.

\section{ACKNOWLEDGMENT}

The authors would like to thank their colleagues, staff, technicians and former students of the Civil Engineering Department, De La Salle University - Manila, especially Lance Hencer Go, Patrick Jerwin Lim, Christine Joy Tan and John Robert Teng. 


\section{REFERENCES}

Baccay, M. A., Otsuki, N., Nishida, T., Maglangbayan, M., \& Saito, T. (2008). Proposed two-dimensional model for estimating the rate of steel corrosion in existing reinforced concrete (RC) structure. 33rd Conference on Our World in Concrete Structures, (pp. 137-146). Singapore.

CeMAP. (2015). Annual Cement Industry Report. Pasig City, Philippines: Cement Manufacturers' Association of the Philippines (CeMAP).

CSI. (2015). Cement Sustainabiity Initiative. Europe: World Business Council for Sustainable Development.

DOE. (2018). Coal. Retrieved from Department of Energy: https://www.doe.gov.ph/energy-statistics?q=coal-overview

Maaddawy, T. A., \& Soudki, K. A. (2003, February). Effectiveness of impressed current technique to simulate corrosion of steel reinforcement in concrete. Journal of Materials in Civil Engineering, 5(1), 41-47.

Miyazato, S., \& Otsuki, N. (2010, June). Steel corrosion induced by chloride or carbonation in mortar with bending cracks or joints. Journal of Advanced Concrete Technology, 8(2), 135-144.

Nanayakkara, O., \& Kato, Y. (2009, February). Macrocell corrosion in reinforcement of concrete under non-homogeneous chloride environment. Journal of Advanced Concrete Technology, 7(1), 31-40.

NSCP. (2013). Chapter 4: Structural Concrete. In National Structural Code of the Philippines (pp. 32-33). Quezon City, Philippines: Association of Structural Engineers of the Philippines.

PEI. (2015, June 30). Philippines set for 23 new coal-fired power plants. Philippine Engineering International. Retrieved February 2017, from http://www.powerengineeringint.com/articles/2015/06/23-new-coal-firedpower-plants-for-philippines.html

Roxas, C., \& Lejano, B. (2018, February). Macrocell Corrosion Assessment Of Steel In Cold-Jointed Concrete Mixed And Cured In Seawater. International Journal of GEOMATE, 14(42), 83-39.

Sandelin, K., \& Backman, R. (2001). Trace elements in two pulverized coal-fired power stations. Environmental Science and Technology, 35(5), 826-834.

Statista. (2018). Global cment production from 1990 to 2030 (in million metric tons). Retrieved from The Statistal Portal: https://www.statista.com/statistics/373845/global-cement-productionforecast/

Swaine, D. (2000). Why trace elements are important? Fuel Processing Technology, 65-66: 21-33. 
UNSDG. (2018). United Nations Sustainable Development Goals. Retrieved November 2018 , from https://www.un.org/sustainabledevelopment/sustainable-development-goals/ Water, U. N. (2012). Managing Ater under Uncertainty and Risk: The United Nation World Water Development Report Volume 1. United Nations Educational Scientific and Cultural Organization (UNESCO).

WCED. (1987). World Commission on Environment and Development: Our Common Future. Oxford University Press.

Williams, D. (2015, June 30). Philippines set for 23 new coal-fired power plants. Power Engineering International. 